\title{
PHYTOPLANKTON-ALORICATE CILIATE COMMUNITY IN THE BAHÍA BLANCA ESTUARY (ARGENTINA): SEASONAL PATTERNS AND TROPHIC GROUPS
}

\author{
Rosa E. Pettigrosso ${ }^{1}$ and Cecilia A. Popovich ${ }^{2}$ \\ ${ }^{1}$ Universidad Nacional del Sur \\ Departamento de Biología, Bioquímica y Farmacia - Laboratorio de Ecología Acuática \\ (San Juan 670, 8000 Bahía Blanca, Argentina) \\ ${ }^{2}$ Universidad Nacional del Sur \\ Departamento de Biología, Bioquímica y Farmacia - Laboratorio de Ficología y Micología \\ (San Juan 670, 8000 Bahía Blanca, Argentina) \\ *Corresponding Author: Email: fipetti@criba.edu.ar
}

\section{A B S T R A C T}

The seasonal pattern of the phytoplankton-aloricate ciliate community is an adequate indicator of trophic coupling and nutrient cycling in coastal environments. The size-fractionated, abundance, biomass and composition of a phytoplankton-aloricate ciliate community were ascertained in the Bahía Blanca Estuary from February 1994 to February 1995. In addition, ciliate production and excretion rates by size class were estimated. A winter-early spring diatom bloom was the most important event in the annual cycle. To evaluate the significance of phytoplankton size in the food web, $<25 \mu \mathrm{m}$ and $>25 \mu \mathrm{m}$ fractions of chlorophyll $a$ were determined; the $<25 \mu \mathrm{m}$ fraction was dominant. To classify the ciliate community in trophic groups, it was divided into volume-size classes, from $\left\langle 10^{3} \mu \mathrm{m}^{3}\right.$ to $>10^{5} \mu \mathrm{m}^{3}$; this wide range of size indicated the potential prey. The smaller ciliates dominated abundance but the larger ones dominated biomass. Values of total ciliates, ranging from 0.2 to $5.2 \times 10^{3}$ cells $\mathrm{L}^{-1}$ and 0.55 to $83.9 \mu \mathrm{g} \mathrm{C} \mathrm{L}^{-1}$, and levels of total chlorophyll $a$ reached 40.4 $\mu \mathrm{g} \mathrm{L}^{-1}$ and were higher than those recorded for other temperate estuarine systems. The smaller ciliates were potentially important as nitrogen regenerators in summer and spring, when their estimated production was highest. The annual potential production of $3 \mathrm{mg} \mathrm{C} \mathrm{L}^{-1}$ represents a reference parameter from which possible changes in the trophic status of this environment could be predicted.

\section{RESUMO}

O padrão sazonal da comunidade de fitoplâncton-ciliados aloricados é um indicador adequado das relações tróficas e reciclagem de nutrientes nos ambientes costeiros. A abundância, biomassa e composição da comunidade de fitoplâncton-ciliados foram determinadas por classes de tamanho durante um ciclo anual no estuário de Bahía Blanca. Além disso, foram estimadas também a produção e as taxas de excreção de ciliados. Uma floração de diatomáceas no período de fim de inverno e início de primavera foi o acontecimento mais importante do ciclo anual. Para avaliar a significância do tamanho do fitoplâncton em relação ao tamanho dos ciliados, foram determinadas as frações de clorofila de $<25 \mu \mathrm{m}$ e $>25 \mu \mathrm{m}$. A fração $<25 \mu \mathrm{m}$ foi dominante. As classes de tamanho dos ciliados determinadas entre $<10^{3} \mathrm{a}>10^{5} \mu \mathrm{m}^{3}$ foram indicadoras da presença de diferentes grupos tróficos e, consequentemente, da variedade das suas presas potenciais. Os ciliados pequenos dominaram em abundância e os maiores em biomassa. A abundância total de ciliados variou de 0,2 a $5,2 \times 10^{3}$ células $\mathrm{L}^{-1}$ e de 0,55 a $83,9 \mu \mathrm{g} \mathrm{C} \mathrm{L}{ }^{-1}$. A concentração de clorofila $a$ total de até $40,4 \mu \mathrm{g} \mathrm{L}^{-1}$ foi superior às registradas em outros sistemas de estuários em regiões temperadas. Os ciliados menores foram importantes como regeneradores de nitrogênio no verão e na primavera, quando a sua produção estimada foi mais alta. A produção potencial anual de $3 \mathrm{mg} \mathrm{C} \mathrm{L}^{-1}$ representa um importante parâmetro de referência na qual possíveis mudanças do status trófico deste ambiente podem ser previstas.

Descriptors: Aloricate ciliates, Phytoplankton, Size-fractioned chlorophyll a, Trophic status, Estuary, Argentina.

Descritores: Ciliados aloricados, Fitoplâncton, Frações de clorofila a, Status trófico, Estuário, Argentina. 


\section{INTRODUCTION}

The advance in knowledge concerning the structure of food webs and their control factors will contribute greatly to a better understanding of the functioning of ecosystems, thus enabling us to predict changes in some of their components. Small planktonic organisms, either almost unknown or largely overlooked until recently, are important components of the pelagic food web. They are collectively known as the "microbial food web" and have been reported to be ubiquitous and abundant in coastal as well as oceanic environments (GARRISON et al., 2000).

Ciliates are among the most important marine microorganisms and constitute a variable group of taxa, ranging, as they do, in size and volume over several orders of magnitude. They exhibit a variety of nutritional habits and metabolic rates which significantly contribute to nutrient cycling. It has also been stressed that ciliates are an important food source for metazoan predators and fish larvae and play a key role in transferring energy from primary production to higher trophic levels (LYNN et al., 1991; PIERCE; TURNER, 1992; LEAKEY et al., 1994; TAKASHI; TANIGUCHI, 2003; KARAYANNI et al., 2004).

Little is known about the global distribution of aloricate planktonic ciliates, but in terms of abundance, biomass and production they have been found to be more important than tintinnids in estuarine, coastal and pelagic waters (SMETACEK, 1981; PIERCE; TURNER, 1992; LEAKEY et al., 1992; PETZ, 1999; TAKASHI; TANIGUCHI, 2003). Some quantitative studies have been carried out on the ciliates of the Bahía Blanca Estuary (BARRIA DE CAO, 1992; BARRIA DE CAO et al., 1997; PETTIGROSSO et al., 1997; BARRIA DE CAO et al., 2005; HOFFMEYER; BARRIA DE CAO, 2007), but in this area, however, no information is available about the seasonal patterns and trophic relationships of the aloricated planktonic ciliates. On the other hand, long-term phytoplankton studies indicate that a diatom winter-early spring bloom is a recurrent feature in the annual cycle and represents the most important event for the production of biomass (GAYOSO, 1998, 1999; POPOVICH; MARCOVECCHIO, 2008).

In the present study we have ascertained the abundance, biomass, composition, and the potential trophic link of the phytoplankton-aloricate ciliate community in the Bahía Blanca estuary over a whole year. The excretion rates and the potential production by ciliate size classes have been estimated on the basis of these results. The integration of all this information is presented and discussed as an advance in the knowledge of the estuarine trophodynamics.
Study Area

This study was carried out in the Bahía Blanca Estuary, located in a semiarid zone of the southern Atlantic coast, in Argentina, at 38 42'$39^{\circ} 25^{\prime} \mathrm{S}, 61^{\circ} 50^{\prime}-62^{\circ} 22^{\prime} \mathrm{W}$. It has a total length of 68 $\mathrm{km}$ and its width ranges from $200 \mathrm{~m}$ at its head to 3-4 $\mathrm{km}$ at its mouth. The sampling station, located in the inner zone (Fig. 1), is a shallow system $(7 \mathrm{~m}$ mean depth) characterized by high turbidity due to the large amount of suspended organic and inorganic material and also hypersalinity, particularly during dry and hot summers (MARCOVECCHIO; FREIJE, 2004). The water column is vertically homogeneous throughout the estuary, although it may be partially mixed in the inner zone depending on the freshwater runoff conditions (PICCOLO et al., 1990). Strong winds and semidiurnal tidal waves dominate the general circulation of the estuary (PICCOLO; PERILLO, 1990). The Sauce Chico River discharges its waters into the innermost region of the estuary, with a mean annual runoff of $1.9 \mathrm{~m}^{3} . \mathrm{s}^{-1}$ although the autumn rainfall may increase this rate to flows of up to 106 $\mathrm{m}^{3} \cdot \mathrm{s}^{-1}$ (PICCOLO et al., 1990). Dissolved oxygen values are usually close to saturation level as a result of the high dynamics of the system, which stimulates both oxidation and remineralization of organic matter within the system. It is, therefore, common to observe supersaturating oxygen levels of up to $130 \%$ during the typical winter/early spring phytoplankton bloom in the estuary (MARCOVECCHIO; FREIJE, 2004). Nutrient concentrations are also high except during the bloom period when they show a remarkable decrease as a result of phytoplankton consumption (POPOVICH et al., 2008a).

\section{Materials and Methods}

Sampling was performed at weekly intervals during daylight hours and during high tide from February 1994 to February 1995 at the Puerto Cuatreros station (Fig. 1). Water samples were collected near the surface (approx. $0.5 \mathrm{~m}$ deep) using a $2.5 \mathrm{~L}$ Van Dorn bottle sampler and they were subsequently used for the analysis of salinity, dissolved inorganic nutrients, particulate organic matter (POM), ciliate composition and abundance, chlorophyll $a$ (Chl-a), phaeopigments and phytoplankton abundance.

Water temperature $\left({ }^{\circ} \mathrm{C}\right)$ and salinity were determined by means of a surface thermometer and a Beckman salinometer, respectively. The water column transparency was estimated based on the Secchi disk depth. Water samples were filtered through a Whatman GF/C to study dissolved inorganic nutrients 


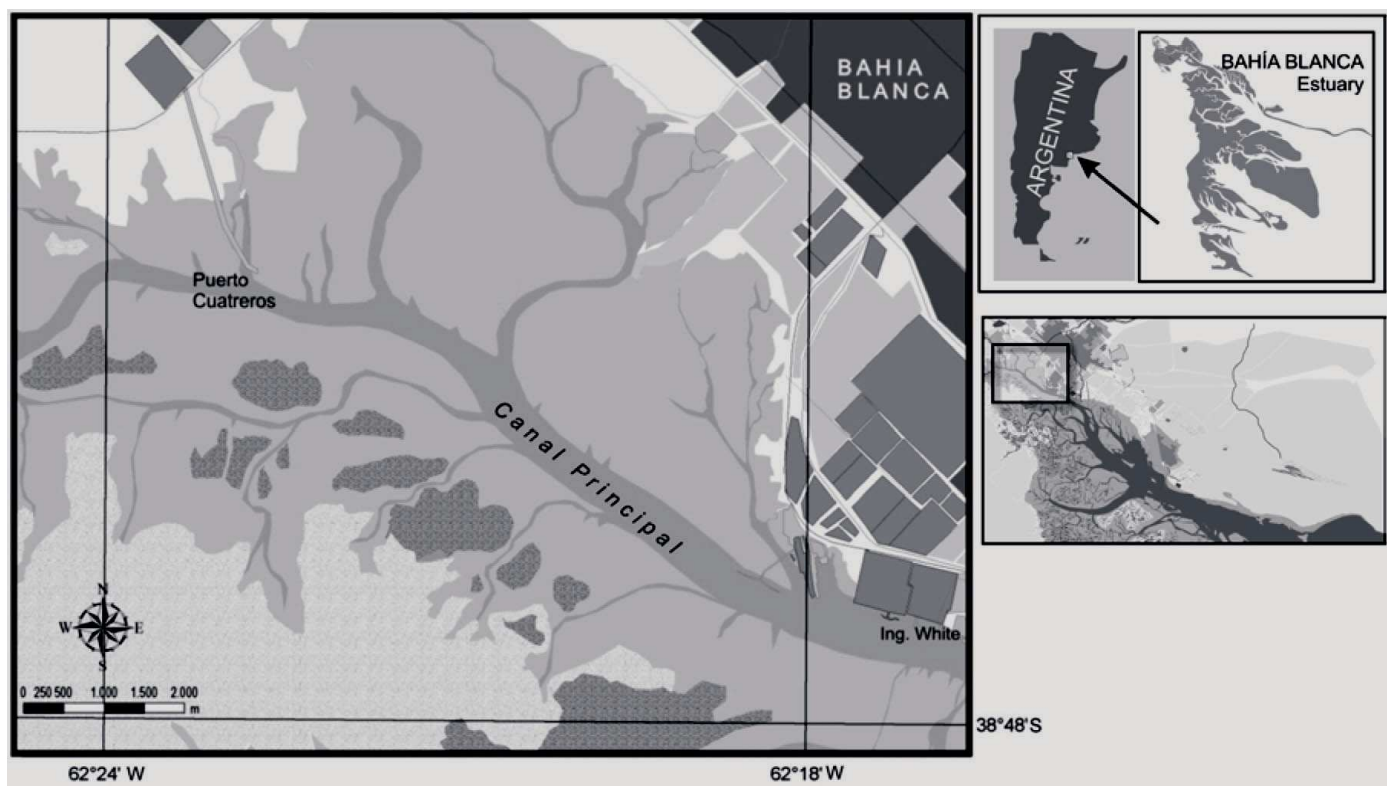

Fig. 1. Map of the Bahía Blanca estuary showing the location of the sampling station (Puerto Cuatreros).

and POM and were frozen until they could be analyzed. Levels of nitrate $\left(\mathrm{NO}_{3}{ }^{-}\right)$, nitrite $\left(\mathrm{NO}_{2}{ }^{-}\right)$, phosphate $\left(\mathrm{PO}_{4}{ }^{3-}\right)$ and silicate were determined in accordance with the methods of TREGUER; LE CORRE (1975), GRASSHOFF et al. (1983), EBERLEIN; KATTNER (1987) and TECHNICON® (1973), respectively, using a Technicon AA-II Autoanalyzer. Dissolved inorganic nitrogen concentrations $(\mu \mathrm{M}$ DIN) were calculated from the sum of nitrate and nitrite; dissolved inorganic phosphate concentrations and dissolved inorganic silicate concentrations were expressed as $\mu \mathrm{M}$ DIP and $\mu \mathrm{M}$ DIS, respectively. POM was determined by a slightly modified method of STRICKLAND; PARSONS (1972). This latter involves the wet oxidation of carbon by sulfuric acid-dichromate oxidant adapted to a spectrophotometer. A Beckman DU2, UV-visible spectrophotometer at a $440 \mathrm{~nm}$ wavelength was used for the determination of organic matter concentrations. Chl- $a$ and phaeopigments were determined spectrophotometrically in accordance with LORENZEN; JEFFREY (1980) from $250 \mathrm{~mL}$ samples filtered through Whatman GF/C membranes, which were stored at $-20^{\circ} \mathrm{C}$ until being used for analytical treatment. The pigment extraction was undertaken in $90 \%$ acetone for 20 minutes at ambient temperature.

Taking into account that in this environment the dominant phytoplankton species form chains during the winter bloom and also that their cell ranges vary significantly around $20 \mu \mathrm{m}$ (PETTIGROSSO et al., 1997; GAYOSO, 1999), it is difficult to separate the nannoplanktonic and microplanktonic fractions as in the traditional classification of SIEBURTH et al. (1978). In this study, therefore, we have used a relatively high value to establish the limit between the two fractions of phytoplankton under study. So the subsample was pre-filtered through a $25 \mu \mathrm{m}$ nylon mesh to estimate the Chl- $a$ in the $<25 \mu \mathrm{m}$ size fraction (nannoplanktonic fraction). The Chl- $a>25$ $\mu \mathrm{m}$ fraction (microplanktonic fraction) resulted from the difference between the total Chl- $a$ and the Chl- $a<$ $25 \mu \mathrm{m}$. The picoplankton fraction was not determined.

Samples were preserved in $2 \%$ acidified Lugol's solution for the estimation of abundance and biomass of aloricate ciliates (STOECKER et al., 1994; KARAYANNI et al., 2004). After gentle mixing, 50 $\mathrm{mL}$ of the subsample was removed and left for decantation for at least 72 hours prior to the analysis using an inverted microscope (HASLE, 1978). Samples were stored in the dark at room temperature and were analyzed within three months of the sampling date.

All the ciliates in the chamber were counted and the linear dimensions (length and diameter) of each cell were measured at 400x magnification, using a calibrated ocular micrometer on a Wild M40 inverted microscope. Taxonomic identification of the samples fixed with Lugol's solution was not possible because it requires specific cytological staining and so ciliates were classified into volume-size classes: $<10^{3}$ $\mu \mathrm{m}^{3}, 10^{3}-10^{4} \mu \mathrm{m}^{3}, 10^{4}-10^{5} \mu \mathrm{m}^{3}$ and $>10^{5} \mu \mathrm{m}^{3}$. Ciliate volumes were estimated by associating the shape of each ciliate with standard geometric configurations (MONTAGNES et al., 1988; LEAKEY et al., 1992). 
The mean cell volume of the different size classes was multiplied by ciliate abundance for the determination of the community biovolume. Ciliate carbon biomass (CCB) was estimated by converting cell volume into carbon weight using a factor of 0.19 pg C $\mu \mathrm{m}^{3}$ (PUTT; STOECKER, 1989) and was

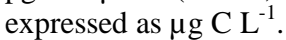

The samples for the quantitative analysis of phytoplankton were preserved in acidified Lugol's solution. The cellular abundance (in cells $\mathrm{L}^{-1}$ ) was determined employing a Sedgwick-Rafter chamber (1 mL) (MCALICE, 1971) under a Zeiss Standard R microscope equipped with phase-contrast objectives. The entire chamber was examined at $\times 200$, and each cell was counted as a unit. In addition, strongly diluted samples were placed in settling chambers $(10 \mathrm{~mL})$ and counted under a Wild inverted microscope at $\mathrm{x} 400$, in accordance with the Utermöhl method (HASLE, 1978). Bottle sampling was complemented by surface sampling with a Nansen $30 \mu \mathrm{m}$ net for identification purposes. Samples were preserved with a $4 \%$ formaldehyde solution and examined under a Zeiss Standard R microscope at $1000 \mathrm{x}$ and phase contrast mode. Phytoplankton carbon biomass (PCB) was calculated from Chl- $a$ measurements multiplied by a conversion factor of 30 (CARON et al., 1995) and was expressed as $\mu \mathrm{g} \mathrm{C} \mathrm{L}^{-1}$.

The excretion rate of ciliates was estimated assuming a carbon to nitrogen ratio for ciliates of 4.4 and the specific excretion rates by size class $\left(E, \mathrm{~h}^{-1}\right)$ as a function of their growth rate $\left(G, \mathrm{~h}^{-1}\right)$ (VERITY, 1985; TAKASHI; TANIGUCHI, 2003) and was expressed as $\mu \mathrm{M} \mathrm{N} \mathrm{L}^{-1} \mathrm{~d}^{-1}$.

\section{Data Analysis}

The Pearson's correlation between CCB and PCB and between phytoplankton size-fractioned biomass $\left(\mu \mathrm{g} \mathrm{C} \mathrm{L}^{-1}\right)$ and ciliate size class biomass $(\mu \mathrm{g}$ $\mathrm{C} \mathrm{L}^{-1}$ ) was tested. To characterize the seasonal variations of the ciliates and phytoplankton biomass, the Principal Components Analysis (PCA) was undertaken using the correlation matrix. The variables included were: total phytoplankton biomass $(\mu \mathrm{g} \mathrm{C}$ Phyto $\mathrm{L}^{-1}$ ), total ciliate biomass and the biomass of the ciliate size classes $\left(<10^{3} \mu \mathrm{m}^{3}, 10^{3}-10^{4} \mu \mathrm{m}^{3}, 10^{4}-10^{5}\right.$ $\mu \mathrm{m}^{3}$ and $\left.>10^{5} \mu \mathrm{m}^{3}\right)\left(\mu \mathrm{g} \mathrm{C} \mathrm{L}^{-1}\right)$.

\section{RESUlts}

\section{Environmental Variables}

Seasonal changes in temperature, salinity and nutrient concentrations are shown in Figure 2. Water temperature presented a seasonal pattern, with a range from $5.2^{\circ} \mathrm{C}$ (June 28) to $24^{\circ} \mathrm{C}$ (December 14 and February 9, 1995) and the salinity ranged between 29.6 (August 17) and 39.5 (March 2) (Fig. 2a). Water transparency was extremely low, Secchi disk depth ranged from 0.35 to $1 \mathrm{~m}$. Dissolved inorganic nutrients were generally high and showed a seasonal pattern characterized by higher values in summer-autumn and lower ones in winter after the diatom bloom. Spring represented a nutrient regeneration season. DIN concentrations ranged from 0.1 to $20.5 \mu \mathrm{M}$, whereas DIP varied between 0.2 and $3.1 \mu \mathrm{M}$, and DIS ranged from 44.1 to $130.2 \mu \mathrm{M}$ (Fig. 2b). POM was relatively high, showing no marked seasonal trends. POM values ranged from 363 to $3561 \mathrm{mg} \mathrm{m}^{-3}$ and the average POM was $1757 \pm 779.6 \mathrm{mg} \mathrm{m}^{-3}$.

\section{Chl-a Concentration and Phytoplankton Abundance}

The seasonal distribution of total and sizefractioned Chl-a for 1994-1995 is shown in Figure 3. A diatom bloom occurred in winter when both Chl- $a$ concentrations and phytoplankton abundance values were highest (up to $40.4 \mu \mathrm{g} \mathrm{L}^{-1}$ and $8.4 \times 10^{6}$ cells $\mathrm{L}^{-1}$, respectively) (Figs 3a-b). The phytoplankton community was dominated by an assemblage of chainforming Thalassiosira and Chaetoceros species (Fig. 3b). Thalassiosira curviseriata (diameter 6-21.5 $\mu \mathrm{m}$ ) was the most common and abundant species during the blooming period (52-98 \%). This species and small species of Chaetoceros (diameter $5-21 \mu \mathrm{m}$ ) were important from June to July and they might be responsible for the Chl- $a<25 \mu \mathrm{m}$ peak $\left(31 \mu \mathrm{g} \mathrm{L}^{-1}\right)$. Larger species of Thalassiosira ( $T$. pacifica, $T$. rotula and $T$. eccentrica ) (diameter 25-46 $\mu \mathrm{m}$ ) were important during July and August and their highest abundance values coincided with the Chl- $a>25 \mu \mathrm{m}$ fraction $\left(20.8 \mu \mathrm{g} \mathrm{L}^{-1}\right)$. In spring, total Chl- $a$ concentrations ranged from 1.15 to $9.43 \mu \mathrm{g} \mathrm{L}^{-1}$, with the Chl- $a<25$ fraction being dominant $(50-99 \%$ of total Chl-a) (Fig. 3a). The diatoms Thalassiosira curviseriata, Guinardia delicatula, Leptocylindrus minimus, Cerataulina pelagica and the dinoflagellates Scripsiella trochoidea were the most important species (Figs 3b-c).

In summer, total Chl-a concentrations varied between 1.4 and $14 \mu \mathrm{g} \mathrm{L}^{-1}$. From December 1994 to February 1995, Chl-a $<25 \mu \mathrm{m}$ was dominant with a peak of $13.4 \mu \mathrm{g} \mathrm{L}^{-1}$ (February, 1995) (Fig. 3a). Phytoflagellates $(10-20 \mu \mathrm{m})$ constituted an important group in these samples with a maximum abundance of $1.2 \times 10^{6}$ cells L $^{-1}$ (February, 1995) (Fig. 3c), whereas Thalassiosira minima (diameter $6 \mu \mathrm{m}$; chain forming) was the most important diatom throughout the summer, reaching $300 \times 10^{3}$ cells L ${ }^{-1}$ (February, 1994) (Fig. 3c). In autumn, total Chl-a concentrations ranged from 2.7 to $12.8 \mu \mathrm{g} \mathrm{L}^{-1}$, the Chl-a > $25 \mu \mathrm{m}$ was dominant and diatoms were the most important phytoplankton group (Fig. 3a). Thalassiosira minima, Cyclotella spp., Thalassiosira sp. (diameter $27 \mu \mathrm{m}$ ), and the tychopelagic species Paralia sulcata and Thalassionema nitzschoides were the most important species (Fig. 3c). 

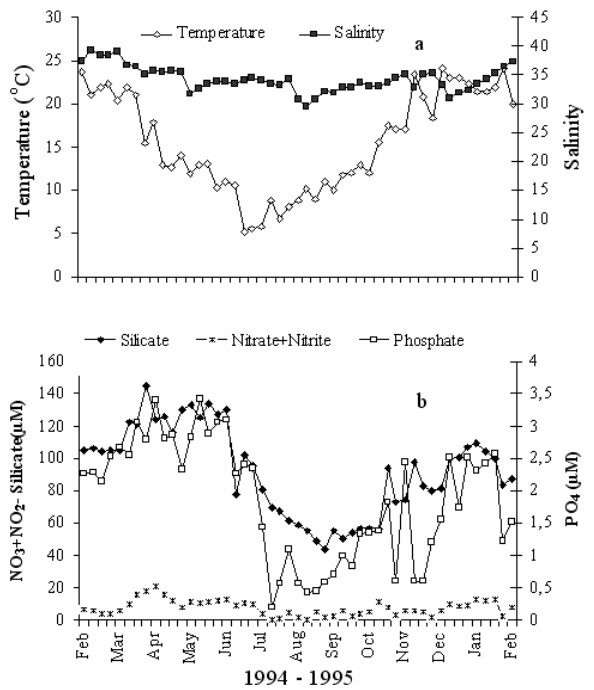

Fig. 2. Seasonal distribution of environmental variables in the Bahía Blanca estuary; temperature $\left({ }^{\circ} \mathrm{C}\right)$ and salinity (a); nutrient concentrations $\left(\mu \mathrm{M} \mathrm{L}^{-1}\right)$ (b).
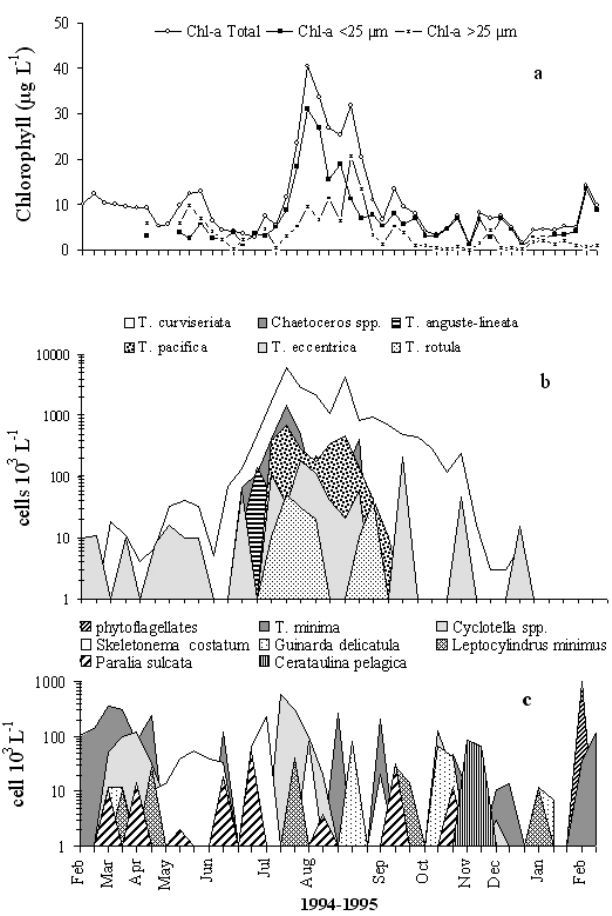

Fig. 3. Seasonal variation of total Chl- $a$ and size-fractioned Chl- $a$ (a); abundance of the most important phytoplankton taxa during an annual cycle: blooming species (b) and nonblooming species (c).

Ciliate Composition and Abundance
The identification of ciliates from samples preserved in acidified Lugol's solution is uncertain below genus level, therefore, for the present study, ciliates were grouped into four size categories: $<10^{3}$ $\mu \mathrm{m}^{3}, 10^{3}-10^{4} \mu \mathrm{m}^{3}, 10^{4}-10^{5} \mu \mathrm{m}^{3}$ and $>10^{5} \mu \mathrm{m}^{3}$ in order to assess their quantitative importance throughout the year according to their sizes.

Although the study site is in the inner zone of the estuary high values of salinity were observed during the study period, so the taxonomic composition of the ciliates was typically estuarine; no fresh water species were found. These species belong to the order Choreotrichida Small and Lynn (Strombidinopsis elongata Song and Bradbury, and Strobilidium epacrum Lynn and Montagnes) and order Strombidiida Petz and Foisner (1992) (Strombidium emergens Leegaard, Strombidium acutum Leegaard, Strombidium capitatum (Leegaard,) Kahl, Strombidium dalum Montagnes and Small and Cyrtrostombidium longisomun Lynn and Gilron,) (PETTIGROSSO, 2003). The rest of the ciliates belonged to the genera Strombidinopsis Kent, Strombidium Claparède and Lachmann, Lohmanniella Leegaard, and Cyclotrichium Meunier (PETTIGROSSO, 2001).

The total abundance of aloricate ciliates ranged from 0.2 to $5.2 \times 10^{3}$ cells $\mathrm{L}^{-1}$ (Table 1). The highest values were observed during the summer of 1995 and the lowest in the winter of 1994 (Fig. 4). The annual cycle was dominated in number by the smallest classes. During autumn the $<10^{3} \mu \mathrm{m}^{3}$ size class represented $75 \%$ of the total abundance and in late winter a conspicuous peak was observed reaching up to $58 \%$. In spring and summer this class represented up to $47 \%$ of the total abundance. Ciliates in the $10^{3}-$ $10^{4} \mu^{3}$ size class reached $\cong 50 \%$ in summer. Values for the abundance of the largest ciliates $\left(10^{4}-10^{5} \mu \mathrm{m}^{3}\right.$ and $>10^{5} \mu \mathrm{m}^{3}$ ) were highest in winter, representing up to 7 and $1.7 \%$, respectively; while their lowest abundance was observed in autumn and spring and they were absent in summer.

\section{Ciliate and Phytoplankton Biomass}

Ciliate carbon biomass (CCB) $\left(\mu \mathrm{g} \mathrm{C} \mathrm{L}^{-1}\right)$ and phytoplankton carbon biomass (PCB) $\left(\mu \mathrm{g} \mathrm{C} \mathrm{L}^{-1}\right)$ are shown in Figure 5. These variables presented a similar trend over the annual cycle analyzed; the maximum levels of $\mathrm{CCB}$ occurred during winter, immediately after the PCB peak (Table 2). Correlation analyses between $\mathrm{CCB}$ and $\mathrm{PCB}$, as well as between the biomass of the ciliate size classes and that of the phytoplankton fractions, over the year are shown in Table 3. 
Table 1. Minimum, maximum and mean values of ciliate abundance (x $10^{3}$ cells $\left.\mathrm{L}^{-1}\right)$ : ciliate size classes $\left(<10^{3} \mu \mathrm{m}^{3}, 10^{3}-10^{4} \mu \mathrm{m}^{3}\right.$, $10^{4}-10^{5} \mu \mathrm{m}^{3}$ and $>10^{5} \mu \mathrm{m}^{3}$ ); total ciliate abundance (TCA).

\begin{tabular}{|c|c|c|c|c|c|}
\hline & $\begin{array}{c}\text { Summer } 1994 \\
\text { Mean }\end{array}$ & $\begin{array}{c}\text { Autumn } \\
\text { Mean }\end{array}$ & $\begin{array}{l}\text { Winter } \\
\text { Mean }\end{array}$ & $\begin{array}{l}\text { Spring } \\
\text { Mean }\end{array}$ & $\begin{array}{c}\text { Summer } 1995 \\
\text { Mean }\end{array}$ \\
\hline & Min $\quad$ Max & Min $\quad$ Max & Min $\quad$ Max & Min $\quad$ Max & Min $\quad$ Max \\
\hline$<10^{3} \mu \mathrm{m}^{3}$ & $\begin{array}{c}0.92 \\
0.2-1.53\end{array}$ & $\begin{array}{c}1.76 \\
0.45-4.3\end{array}$ & $\begin{array}{c}0.9 \\
0.125-2.53\end{array}$ & $\begin{array}{c}0.98 \\
0.2-3.58\end{array}$ & $\begin{array}{c}1.4 \\
0.525-2.83\end{array}$ \\
\hline $10^{3}-10^{4} \mu \mathrm{m}^{3}$ & $\begin{array}{c}0.93 \\
0.33-1.95\end{array}$ & $\begin{array}{c}0.50 \\
0.23-1.05\end{array}$ & $\begin{array}{c}0.51 \\
0.025-2.3\end{array}$ & $\begin{array}{c}1.0 \\
0.35-2.28\end{array}$ & $\begin{array}{c}1.56 \\
0.6-2.35\end{array}$ \\
\hline $10^{4}-10^{5} \mu \mathrm{m}^{3}$ & $\begin{array}{c}0.038 \\
0-0.1\end{array}$ & $\begin{array}{c}0.082 \\
0-0.25\end{array}$ & $\begin{array}{c}0.11 \\
0-0.45\end{array}$ & $\begin{array}{c}0.098 \\
0.025-0.25\end{array}$ & $\begin{array}{c}0.018 \\
0-0.05\end{array}$ \\
\hline$>10^{5} \mu \mathrm{m}^{3}$ & --- & $\begin{array}{c}0.007 \\
0-0.05\end{array}$ & $\begin{array}{c}0.027 \\
0-0.25\end{array}$ & $\begin{array}{c}0.004 \\
0-0.05\end{array}$ & --- \\
\hline TCA & $\begin{array}{c}1.9 \\
0.6-2.7 \\
\end{array}$ & $\begin{array}{c}2.35 \\
0.75-5\end{array}$ & $\begin{array}{c}1.55 \\
0.2-2.95\end{array}$ & $\begin{array}{c}2.08 \\
0.83-4.55\end{array}$ & $\begin{array}{c}2.98 \\
2.28-5.2\end{array}$ \\
\hline
\end{tabular}

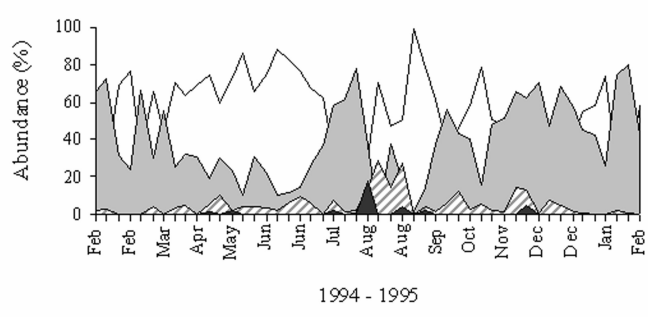

Fig. 4. Seasonal variation of the ciliate abundance (\%) by size-classes over the year. White: $<10^{3} \mu \mathrm{m}^{3}$; grey: $10^{3}$ $10^{4} \mu \mathrm{m}^{3}$; hatched: $10^{4}-10^{5} \mu \mathrm{m}^{3}$; black: $>10^{5} \mu \mathrm{m}^{3}$.

The Principal Component Analysis (PCA) revealed a temporal variability of the phytoplanktonciliate community biomass delineating three main assemblages of samples. The loadings for each variable for the first and second principal components are shown in Figure 6a. PC1 showed both high negative loadings for phytoplankton biomass and > $10^{5} \mu \mathrm{m}^{3}$ ciliate biomass (higher quadrant) and high negative loadings for $10^{4}-10^{5} \mu \mathrm{m}^{3}$ (lower quadrant); in addition, PC1 showed high positive loadings for smallest ciliate biomass $\left(<10^{3} \mu \mathrm{m}^{3}\right)$. PC2 showed high positive loadings with $10^{3}-10^{4} \mu^{3}$. The distribution of sampling data in the plane defined by the first two principal components (Fig. 6b) exhibited a clear segregation of the samples taken in winter of those taken in summer. According to PCA, sampling dates taken in winter were the most representative of the bloom conditions and the larger ciliate presence. The samples taken in the summers 1994-1995 formed another defined group composed principally of the smaller classes of ciliates, while the autumn - spring group showed a different tendency.

Specific excretion rates of the ciliate size classes were estimated to be $0-10.4 \mu \mathrm{M} \mathrm{N} \mathrm{L}^{-1} \mathrm{~d}^{-1}$ during the annual cycle (Table 4). The smaller classes of ciliates showed the maximum level of nitrogen excretion. Thus in summer 1995 the $<10^{3} \mu^{3}$ and $10^{3}-10^{4} \mu \mathrm{m}^{3}$ size classes reached respective levels of nitrogen excretion rates up to 3.8 and $10.4 \mu \mathrm{M} \mathrm{N} \mathrm{L}^{-1}$ $\mathrm{d}^{-1}$.

\section{Discussion}

Seasonal Abundance and Biomass Patterns of the Phytoplankton-Aloricate Ciliate Community

The seasonal patterns of phytoplankton in temperate coastal environments are characterized by great variability and they usually include major blooms during spring and summer and minor ones in early autumn (TRIGUEROS; ORIVE, 2004; DOMINGUES et al., 2005). Moreover, the greatest biomass of ciliates in temperate estuaries and coastal environments follows the pattern of the phytoplankton bloom (LYNN et al., 1991; JOHANSSON et al., 2004). This is the first report of quantitative and qualitative data on aloricate ciliates and phytoplankton from the Argentine estuary. In the Bahía Blanca estuary, the occurrence of a winter-early spring diatom bloom was the most important event of biomass production, as recorded in long-term phytoplankton studies in this environment (GAYOSO, 1998; POPOVICH et al., 2008a). On the other hand, the seasonal pattern of the ciliate community in the Bahía Blanca estuary also showed some differences in the seasonal pattern found in the waters of other temperate regions, which generally show high biomass in spring and autumn and low biomass in summer (SMETACEK, 1981, NIELSEN; KIORBE, 1994). Thus, in the present study maximum levels of ciliate biomass occurred during winter, immediately after the phytoplankton peak, while the highest ciliate abundance values were observed during the summer and the lowest in the winter. 


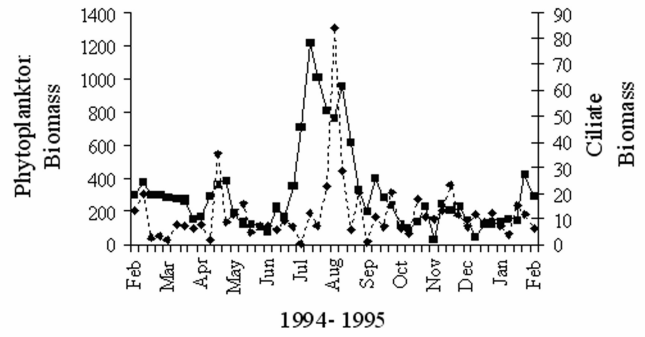

Fig. 5. Total phytoplankton biomass $\left(\mu \mathrm{g} \mathrm{C} \mathrm{L}^{-1}\right)$ (solid line) and total ciliate biomass $\left(\mu \mathrm{g} \mathrm{C} \mathrm{L}^{-1}\right.$ ) (dashed line) in the Bahía Blanca Estuary during 1994 to 1995.

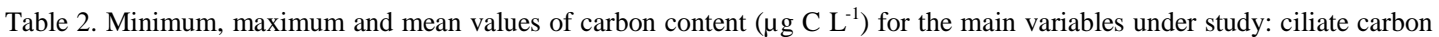
biomass (CCB) and phytoplankton carbon biomass (PCB), carbon biomass of the ciliate size classes $\left(<10^{3} \mu \mathrm{m}^{3}, 10^{3}-10^{4} \mu \mathrm{m}^{3}\right.$, $10^{4}-10^{5} \mu \mathrm{m}^{3}$ and $\left.>10^{5} \mu \mathrm{m}^{3}\right)$; carbon biomass of the phytoplankton fractions $(<25 \mu \mathrm{m}$ and $>25 \mu \mathrm{m})$.

\begin{tabular}{|c|c|c|c|c|c|}
\hline & $\begin{array}{c}\text { Summer (1994) } \\
\text { Mean }\end{array}$ & $\begin{array}{l}\text { Autumn } \\
\text { Mean }\end{array}$ & $\begin{array}{l}\text { Winter } \\
\text { Mean }\end{array}$ & $\begin{array}{l}\text { Spring } \\
\text { Mean }\end{array}$ & $\begin{array}{c}\text { Summer (1995) } \\
\text { Mean }\end{array}$ \\
\hline & Min $\quad$ Max & Min $\quad$ Max & Min $\quad$ Max & Min $\quad$ Max & Min $\operatorname{Max}$ \\
\hline$<10^{3} \mu \mathrm{m}^{3}$ & $\begin{array}{c}0,82 \\
0.28-1.52\end{array}$ & $\begin{array}{c}1.1 \\
0.24-2.76\end{array}$ & $\begin{array}{c}0.47 \\
0.08-0.88\end{array}$ & $\begin{array}{c}0.76 \\
0.09-1.58\end{array}$ & $\begin{array}{c}1.3 \\
0.57-2.42\end{array}$ \\
\hline $10^{3}-10^{4} \mu \mathrm{m}^{3}$ & $\begin{array}{c}5.94 \\
1.53-16.12\end{array}$ & $\begin{array}{c}3.06 \\
1.30-6.45\end{array}$ & $\begin{array}{c}2.65 \\
0.15-11.83\end{array}$ & $\begin{array}{c}5.43 \\
2.89-9.6\end{array}$ & $\begin{array}{c}7.63 \\
2.71-13.09\end{array}$ \\
\hline $10^{4}-10^{5} \mu \mathrm{m}^{3}$ & $\begin{array}{c}1.42 \\
1.48-3.84\end{array}$ & $\begin{array}{c}4.88 \\
2.09-18.81\end{array}$ & $\begin{array}{c}6.83 \\
1.1-25.33\end{array}$ & $\begin{array}{c}4.98 \\
0.48-13.54\end{array}$ & $\begin{array}{c}0.48 \\
0.5-1.43\end{array}$ \\
\hline$>10^{5} \mu \mathrm{m}^{3}$ & --- & $\begin{array}{c}5.32 \\
0-10.56\end{array}$ & $\begin{array}{c}17.31 \\
5.1-63.6\end{array}$ & $\begin{array}{c}10.04 \\
0-10.4\end{array}$ & --- \\
\hline $\mathrm{CCB}$ & $\begin{array}{c}8.18 \\
2.19-19.97\end{array}$ & $\begin{array}{c}10.51 \\
1.77-35.51\end{array}$ & $\begin{array}{c}16.60 \\
0.56-83.97\end{array}$ & $\begin{array}{c}12 \\
4.56-23.39\end{array}$ & $\begin{array}{c}9.41 \\
3.90-15.25\end{array}$ \\
\hline$<25 \mu \mathrm{m}$ & --- & $\begin{array}{c}77.2 \\
37.2-176.4\end{array}$ & $\begin{array}{c}384.4 \\
88.5-933.3\end{array}$ & $\begin{array}{c}132.4 \\
34.5-282.9\end{array}$ & $\begin{array}{c}159.6 \\
73.5-401.7\end{array}$ \\
\hline$>25 \mu \mathrm{m}$ & --- & $\begin{array}{c}102.2 \\
7.5-294\end{array}$ & $\begin{array}{c}211 \\
15-622.5\end{array}$ & $\begin{array}{c}35.9 \\
1.2-123.9\end{array}$ & $\begin{array}{c}41.8 \\
22.2-62.1\end{array}$ \\
\hline PCB & $\begin{array}{c}306.6 \\
278.4-376.2\end{array}$ & $\begin{array}{c}207.1 \\
82.2-384.9\end{array}$ & $\begin{array}{c}595.5 \\
167.7-1213.5\end{array}$ & $\begin{array}{c}168.3 \\
34.5-282.9\end{array}$ & $\begin{array}{c}201.4 \\
126-423.9\end{array}$ \\
\hline
\end{tabular}

Table 3. Pearson's correlation coefficients among the variables under study: phytoplankton carbon biomass $\left(\mu \mathrm{g} C \mathrm{~L}^{-1} \mathrm{PCB}\right)$; ciliate carbon biomass $\left(\mu \mathrm{g} \mathrm{C} \mathrm{L} \mathrm{C}^{-1} \mathrm{CCB}\right)$; carbon biomass of the ciliate size classes $\left(<10^{3} \mu \mathrm{m}^{3}, 10^{3}-10^{4} \mu \mathrm{m}^{3}, 10^{4}-10^{5} \mu \mathrm{m}^{3}\right.$ and $>10^{5}$ $\left.\mu \mathrm{m}^{3}\right)$; carbon biomass of the phytoplankton fractions $(<25 \mu \mathrm{m}$ and $>25 \mu \mathrm{m})$.

\begin{tabular}{|c|c|c|c|c|c|}
\hline & CCB & $<10^{3} \mu \mathrm{m}^{3}$ & $10^{3}-10^{4} \mu \mathrm{m}^{3}$ & $10^{4}-10^{5} \mu \mathrm{m}^{3}$ & $>10^{5} \mu \mathrm{m}^{3}$ \\
\hline $\mathrm{PCB}$ & $0.633 * *$ & --- & -- & $\mathrm{ns}$ \\
\hline$<25 \mu \mathrm{m}$ & --- & $-0.453 *$ & $\mathrm{~ns}$ & $0.445 *$ \\
\hline$>25 \mu \mathrm{m}$ & --- & $-0.443 *$ & $\mathrm{~ns}$ & $0.676 * * *$ & $0.582 * *$ \\
\hline
\end{tabular}



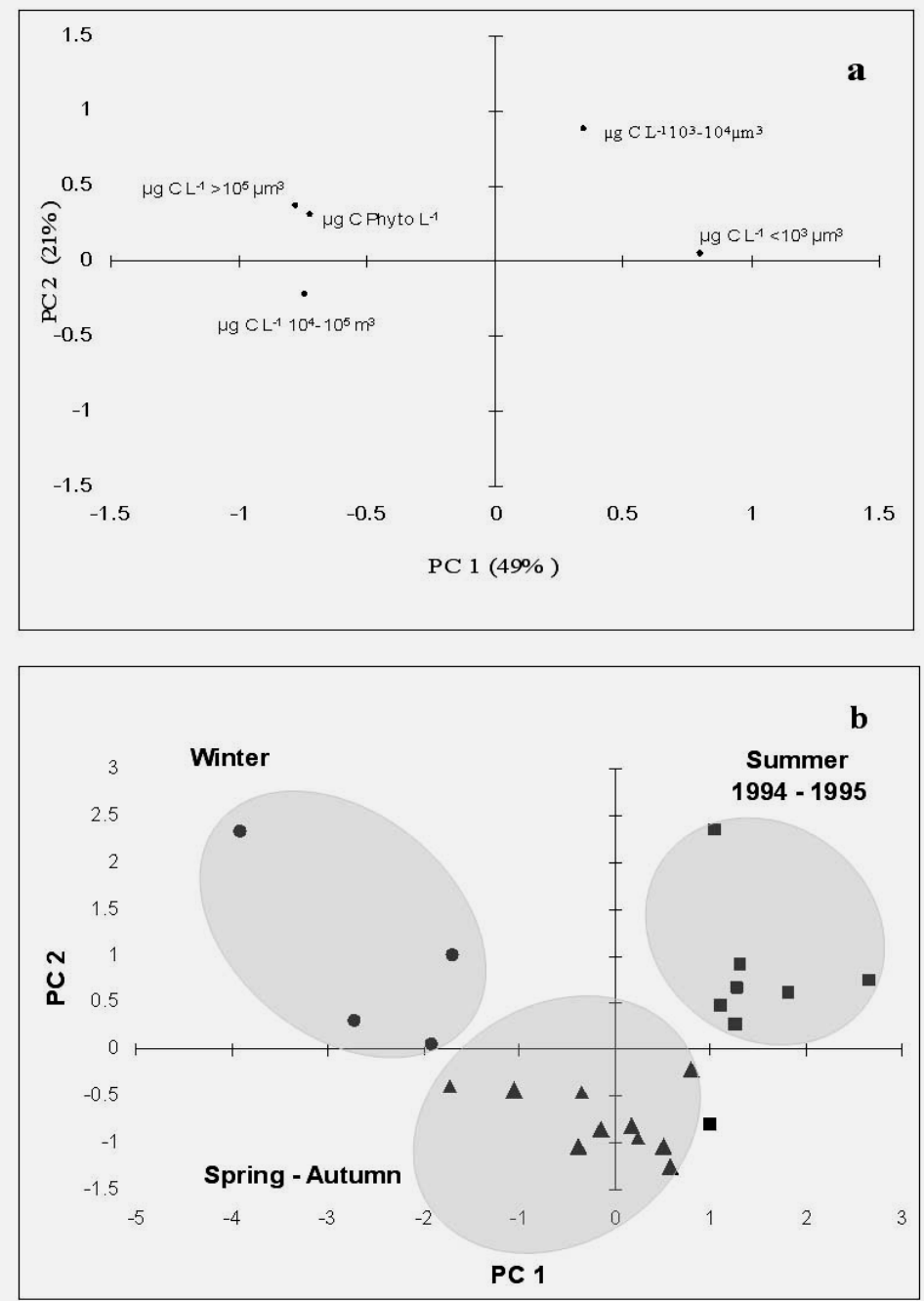

Fig. 6. Principal Components Analysis. (a) Loadings of the major variables on PC1 and PC2; (b) distribution of sampling data in PC1 vs. PC2 space. Triangles represent spring autumn sampling data; circles indicate the winter samples and squares corresponding to the summer samples (1994-1995).

The PCA results revealed that the biomass of the phytoplankton-aloricate ciliate community in the Bahía Blanca Estuary showed a seasonal variability. At least twenty-four different aloricate ciliate taxa were recorded during the annual cycle in the Bahía Blanca estuary, of which seven were later identified to species level using the protargol staining method (PETTIGROSSO, 2003). The assembly of winter dates consisted of large-sized ciliates preying on blooming diatoms, characterized principally by heterotrophic choreotrichs and mixotrophic oligotrichs belonging to the Strombidinopsis and Strombidium genera. The most conspicuous species were Strombidinopsis elongata (97-129 $\mu \mathrm{m}$ in length, 74-82 $\mu \mathrm{m}$ in width) and the mixotrophic Strombidium emergens (27-39 $\mu \mathrm{m}$ in length, $19.5-30 \mu \mathrm{m}$ in width) (PETTIGROSSO, 2003). Large species like Cyrtostrombidium sp. ( $\cong 100 \mu \mathrm{m}$ in length, $45 \mu \mathrm{m}$ in width) and small species of the mixotrophic Lohmanniella and Strombidium genera were present in early winter (PETTIGROSSO, 2001). If choreotrich have an optimum prey size of approximately $15 \%$ of their length (5-30\% range) (JOHANSSON et al., 2004) then, the winter ciliate assemblage had food 
available over a wide size spectrum. Thalassiosira curviseriata and small species of Chaetoceros were common from June to July and the largest species of Thalassiosira were dominant in July and August. Even though diatoms are not considered a good food source for ciliates (IRIGOIEN et al., 2005), in our study we observed ciliates with chains of blooming species of diatoms (PETTIGROSSO, 2001). In addition, significant correlations between the largest size classes of the ciliates and the phytoplankton fractions were obtained $(p<0.001)$. A similar result was observed by Aberle and Lengfellner (2007) who suggest that the potential food spectrum of ciliates is much larger than commonly believed, mainly for aloricate ciliates. Although aloricate ciliates do not have a grazing impact on the phytoplankton during the diatom bloom, as the ciliate biomass represented only $2.8 \%$ of the large phytoplankton biomass, they do not seem to be food-limited either. In this estuary a mixed zooplankton assemblage dominated by the copepod Acartia tonsa showed its maximum abundance in summer (January-March) and the low densities during the phytoplankton bloom (June-August) (HOFFMEYER, 2004). A decrease in the grazing pressure is one of the mechanisms associated with phytoplankton blooms (GAYOSO, 1999) and might help to explain the presence of large-sized ciliates in winter.

The summer assemblage was constituted of smaller ciliates, represented by species belonging to the Strombidium and Strombidinopsis genera, with a size range from $<30$ to $50 \mu \mathrm{m}$, which may consume small prey (RASSOULZADEGAN et al., 1988, LYNN et al., 1991). Negative correlations were significant $(p<0.05)$ between ciliates of the $<10^{3} \mu \mathrm{m}^{3}$ size class and the $<25 \mu \mathrm{m}$ phytoplankton fraction. These observations suggest that these ciliates are closely linked to the small-sized phytoplankters and the peaks of phytoflagellates and small diatoms (i.e. Thalassiosira minima) observed in this study are a potential food source. In this season, the ciliate biomass ranged from $2.67 \%$ to $4.67 \%$ in respect to the phytoplankton standing stock. These values could be a consequence of the zooplankton predation pressure on the largest ciliates as has been reported in other coastal areas (SANDERS; WICKHAM, 1993; LONSDALE et al., 1996; JOHANSSON et al., 2004).

The autumn-spring assemblage was composed of all the size classes, suggesting a complex trophic role of the ciliates during these seasons. Ciliates $<10^{3} \mu \mathrm{m}^{3}$ in size were numerically dominant in autumn and the $10^{3}-10^{4} \mu \mathrm{m}^{3}$ size classes were more prevalent in spring. During autumn a very small number of large ciliates, mainly $10^{4}-10^{5} \mu \mathrm{m}^{3}$ in size, and the presence of heavily silicified and large diatoms species, such as Paralia sulcata, Gyrosigma attenuatum and Thalasionema nitzschioides were observed. At this time of year these diatoms are considered to be indicators of a high resuspension due to the vertical mixing of the water column and they do not constitute an adequate food for the ciliates. The standing stock of ciliates was equivalent to $5 \%$ of the phytoplankton, which may be explained by a low copepod grazing pressure on the largest ciliates due to a greater supply of food of suitable size by the presence of large phytoplankton cells. On the other hand, large dinoflagellates that can graze on ciliates were not to be detected.

In spring, Strobilidium epacrum (length 35$55 \mu \mathrm{m}, 31-47 \mu \mathrm{m}$ width), the mixotrophic Strombidium capitatum (23-55 $\mu \mathrm{m}$ length, 39-55 $\mu \mathrm{m}$ width) (PETTIGROSSO, 2003) and a large Strombidinopsis sp. were common, being present during the last phase of the phytoplankton bloom which was characterized by larger blooming and non-blooming species, such as Guinardia delicatula and Scripsiella trochoidea. The smaller classes of ciliates were composed mainly of small species, such as the mixotrophics Strombidium acutum (27-33 $\mu \mathrm{m}$ in length, 27-35 $\mu \mathrm{m}$ in width) and Strombidium dalum $(20 \mu \mathrm{m}$ in length, $12 \mu \mathrm{m}$ in width) (PETTIGROSSO, 2003). The average standing stock of the ciliates of $7 \%$ of the phytoplankton, the highest as compared with other seasons, evidences a phase of heterotrophic transition in the food chain.

Table 4 . Specific excretion rates of the ciliates size classes by season.

\begin{tabular}{|c|c|c|c|c|c|c|c|c|c|c|}
\hline & \multicolumn{2}{|c|}{$\begin{array}{c}\text { Summer } \\
(1994)\end{array}$} & \multicolumn{2}{|c|}{ Autumn } & \multicolumn{2}{|c|}{ Winter } & \multicolumn{2}{|c|}{ Spring } & \multicolumn{2}{|c|}{$\begin{array}{c}\text { Summer } \\
(1995)\end{array}$} \\
\hline & Min & $\operatorname{Max}$ & Min & Max & Min & Max & Min & Max & Min & $\operatorname{Max}$ \\
\hline$<10^{3}$ & 0.233 & 2.188 & 0.0854 & 0.8882 & 0.0072 & 0.1622 & 0.0497 & 1.6854 & 0.9739 & 3.8239 \\
\hline $10^{3}-10^{4}$ & 0.901 & 8.728 & 0.130 & 3.053 & 0.008 & 0.437 & 0.21 & 3.47 & 1.607 & 10.438 \\
\hline $10^{4}-10^{5}$ & 0 & 0.948 & 0 & 0.5081 & 0 & 0.470 & 0.059 & 2.289 & 0 & 0.405 \\
\hline$>10^{5}$ & 0 & 0 & 0 & 0.1762 & 0 & 0.439 & 0 & 0.8970 & 0 & 0 \\
\hline
\end{tabular}


The mechanisms causing fluctuation of marine planktonic ciliate populations have not been fully elucidated to date. Some field studies have suggested a food control (bottom- up control) whereas others have demonstrated that ciliate populations are controlled by mesozooplankton predation (top-down control) (NIELSEN; KIØRBOE, 1994; PIERCE; TURNER, 1992; BOISSONNEAULT et al., 2001). In the Bahía Blanca estuary, a significant positive correlation between total phytoplankton biomass and total ciliate biomass $(p<0.01)$ suggests that ciliate populations were rarely if ever limited by food availability. On the other hand, high SPM concentrations reported in the inner zone of Bahía Blanca estuary (PERILLO; PICCOLO, 1999) and the high POM values reported in this study represent another potential food source for the smallest ciliates, as has been observed in other environments (HIETANEN, 1998). Moreover, the results of this study allow us to infer that in this ecosystem a ciliatecopepod link exists by a top down mechanism. High copepod predation on largest ciliates when nano-sized food dominates, added to low predation in winter when adult copepods are absent, could explain why ciliate biomass peaked in concordance with the phytoplankton bloom.

\section{Ciliate Production and Excretion}

The role of planktonic ciliates as primary consumers of pico- and nano-sized producers has been recognized in several environments (TAKASHI; TANIGUCHI, 2003). Thus, the production of ciliates during the annual cycle in the Bahía Blanca Estuary was estimated from the empirical formula proposed by Montagnes et al. (1988) for each sampling date. This equation assumes that food availability is not limiting. The concentrations of Chl- $a$ recorded in Puerto Cuatreros during 1994-1995 are compatible with those observed by Leakey et al. (1992), who considered that ciliates from Southampton waters were not limited by food. The daily ciliate production obtained from Puerto Cuatreros ranged from 0.13 to $29 \mu \mathrm{g} \mathrm{C} \mathrm{L}^{-1} \mathrm{~d}^{-1}$, with the highest values in summer, when high temperatures $\left(22-24^{\circ} \mathrm{C}\right)$ provide a suitable environment for ciliate growth. The potential annual production estimated was $3 \mathrm{mg} \mathrm{C} \mathrm{L}^{-1} \mathrm{y}^{-1}$ and ciliates belonging to the $10^{3}-10^{4} \mu^{3}$ size class were the main contributors to total productivity over the annual cycle. Our results revealed that the values corresponding to the annual potential production of ciliates in the Bahía Blanca estuary were higher than those corresponding to more oligotrophic environments (MONTAGNES et al., 1988) and lower than those obtained in environments reported to be highly productive and eutrophic (LEAKEY et al., 1992). Based on these observations, we suggest that the inner zone of Bahía Blanca estuary is a moderately eutrophic environment. Another important role of ciliates is as nutrient regenerators in the epipelagic zone (TAKASHI; TANIGUCHI, 2003). Specifically, ciliates have been recognized as important sources of $\mathrm{NH}_{4}^{+}$("regenerated nitrogen") in shallow coastal environments where tributary inputs are low (LEWITUS et al., 1998; BODE et al., 2005). Studies carried out in the inner zone of the Bahía Blanca Estuary since 2000 have indicated a prevalence of $\mathrm{NH}_{4}{ }^{+}$over nitrate as the main form of available nitrogen (MARCOVECCHIO; FREIJE, 2004). In addition, POPOVICH et al. (2008a) have suggested that the occurrence of a trophic coupling between aloricate ciliates and blooming diatom populations may represent a potential source of regenerated nitrogen after bloom. Specific excretion rates of the ciliate size classes estimated in this study seem to partially confirm this hypothesis. Thus, according to our results (Table 5), the ciliates belonging to $<10^{3}$ $\mu \mathrm{m}^{3}$ and $10^{3}-10^{4} \mu \mathrm{m}^{3}$ size classes reached maximum levels of nitrogen excretion rates in summer (2.2-3.8 and 8.7-10.4, respectively) and spring (1.7 and 3.47, respectively) acting as important seasonal nutrient regenerators and contributing to the nitrogen requirement by primary producers. These values suggest that the nitrogen excretion by ciliates could be a significant contribution to sustainable primary productivity during summer and spring in this environment.

Taken together, although there are no records of previous studies on the seasonal variation of the biomass of aloricate ciliates in the Bahía Blanca estuary we assume that the seasonal pattern observed during this study is within what would be expected, taking into account that the seasonal succession of phytoplankton during 1994-1995 was similar in duration and magnitude to that reported in previous studies carried out in this environment (GAYOSO, 1998). In this context, knowledge of the dynamics of the groups that make up the plankton community and their reaction to environmental factors is a valuable tool that could help to predict possible changes related to anthropogenic and/or natural causes. In this regard, Aberle and Lengfellner (2007) showed that an increase in the winter temperature produced accelerated growth and therefore large increases in ciliate biomass, altering the specific composition and creating an asynchrony between the components of the plankton. Changes in the seasonal pattern of the diatom bloom and the ciliate biomass have been observed over the last few years (POPOVICH et al., 2008b) and will be studied in the near future. 


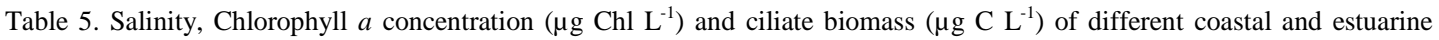
environments.

\begin{tabular}{|c|c|c|c|c|}
\hline Location & Salinity & $\begin{array}{l}\text { Chlorophyll } a \\
\text { concentration }\end{array}$ & $\begin{array}{l}\text { Heterotrophic Ciliate } \\
\text { Biomass }\end{array}$ & Reference \\
\hline Kiel Bight & $13-20$ & $\sim 1-10$ & $1-56$ & Smetacek (1981) \\
\hline Damariscotta Estuary & $\sim 29-33$ & $0.23-6.2$ & $0.4-33$ & $\begin{array}{l}\text { Revelante and Gilmartin } \\
\qquad(1987)\end{array}$ \\
\hline Gulf of Maine & $30-32$ & -- & $<1-5.7$ & Montagnes et al. (1988) \\
\hline $\begin{array}{l}\text { Southampton Water } \\
\text { N. W. Netley }\end{array}$ & $29-34$ & $1-27$ & $1.4-219$ & Leakey et al. (1992) \\
\hline $\begin{array}{c}\text { Lower St. Lawrence } \\
\text { Estuary }\end{array}$ & $28.4-29.2$ & $0.03-9.63$ & $0.23-51.59$ & Sime-Nagando et al. (1995) \\
\hline Baltic Sea & $\sim 5.1-6.9$ & -- & $1.1-13$ & Johansson et al. (2004) \\
\hline Bahía Blanca Estuary & $29.6-39.5$ & $1.15-40.4$ & $0.55-84$ & This Study \\
\hline
\end{tabular}

\section{ACKNOWLEDGEMENTS}

The present research was supported by a grant from the Universidad Nacional del Sur to Dra. Ana María Gayoso (C.O.N.I.C.E.T). Attendance at the Laboratory of Protozoology of the Zoology Department at the University of Guelph, Canada, was supported by FOMEC (Con. Pas. 407/00). We especially thank Dr. Denis Lynn for his positive comments on the manuscript and María José Boavida for her suggestions about the earlier versions of the manuscript. We would like to thank the Marine Chemistry Laboratory of the Instituto Argentino de Oceanografía (I.A.D.O), to Dr. Inácio Domingos da Silva Neto who helped us with the translation into Portuguese and to the anonymous reviewers for their constructive suggestions.

\section{REFERENCES}

ABERLE, N. K.; LENGFELLNER, U. S. Spring bloom succession, grazing impact and herbivore selectivity of ciliate communities in response to winter warming. Oecologia, v. 150, p. 668-681, 2007.

BARRIA DE CAO, M. S. Abundance and species composition of tintinnina (Ciliophora) in Bahía Blanca estuary, Argentina. Estuar. coast. Shelf Sci., v. 34, p. 295-303, 1992.

BARRIA DE CAO, M. S.; PETTIGROSSO, R. E.; C. A. POPOVICH. Planktonic ciliates during a diatom bloom in Bahía Blanca Estuary, Argentina. II Tintinnids. Oebalia, v. 23, p. 21-31, 1997.

BARRIA DE CAO, M. S.; BEIGT, D.; PICCOLO, C. Temporal variability of diversity and biomass of tintinnids (Ciliophora) in a southwestern Atlantic temperate estuary. J. Plakt. Res., v. 27, n.11, p.11031111, 2005.

BODE, A.; GONZALEZ, N.; RODRIGUEZ, C.; VARELA, M.; VARELA, M. M. Seasonal variability of plankton blooms in the Ria de Ferrol (NW Spain): I. Nutrient concentrations and nitrogen uptake rates. Estuar. coast. Shelf Sci., v. 63, p. 269-284, 2005.

BOISSONNEAULT-CELLINERI, K. R.; MAUSMI, M.; LONSDALE, D. J.; CARON, D. A. Microbial food web interactions in two Long Island embayments. Aquat. Microbiol. Ecol., v. 26, p. 139-155, 2001.

CARON, D. A.; DAM, H. G.; KREMER, P.; LESSARD, J. E.; MADN, L. P.; MALONE, T. C.; NAPP, J. M.; PEELE, E. R.; ROMAN, M. R.; YOUNGBLUTH, M. J. The contribution of microorganisms to particulate carbon and nitrogen in surface waters of the Sargasso Sea near Bermuda. Deep Sea Res., v. 42, p. 943-972, 1995.

DOMINGUES, R. B.; BARBOSA, A.; GALVÃO, H. Nutrients, light and phytoplankton succession in a temperate estuary (the Guadiana, South-western Iberia). Estuar. coast. Shelf Sci., v. 64, p. 249-260, 2005.

EBERLEIN, K.; KATTNER, G. Automatic method for the determination of ortho-phosphate and total dissolved phosphorus in the marine environment. Fresenius J. analyt. Chem., Berlin, Springer-Verlag, v. 326, p. 354357, 1987.

GARRISON, D. L.; GOWING, M. M.; HUGHES, M. P.; CAMPBELL, L.; CARON, D. A.; DENNETT, M. R.; SHALAPYONONK, A.; OLSON, R. J.; LANDRY, M. R.; BROWN, S. L.; LIU, H. B.; AZAM, F.; STEWARD, G. F.; DUCKLOW, H. W.; C. SMITH, D. Microbial food web structure in the Arabian Sea: a US JGOFS study. Deep Sea Res., II, v. 47, p. 1387-1422, 2000.

GAYOSO, A. M. Long-term phytoplankton studies in the Bahía Blanca estuary, Argentina. ICES J. mar. Sci., v. 55 , p. 665-660, 1998. 
GAYOSO, A. M. Seasonal Succession Patterns of Phytoplankton in the Bahía Blanca estuary (Argentina) Botanica mar., v. 42, p. 367-375, 1999.

GRASSHOFF, K.; EHRHARDT, M.; KREMLING, K. Methods of seawater analysis. Weinheim: Verlag Chemie, 1983. 365 p.

HASLE, G. R.. Using the inverted microscope. In: SOURNIA, A. (Ed.). Phytoplankton manual. Paris: UNESCO, 1978. p. 191-196.

HIETANEN, S. Literature review on microbiology of aggregates originating from phytoplankton blooms. Meri, v. 37, p. $37-44,1998$.

HOFFMEYER, M. S. Meso-Zooplancton.. In: PICCOLO, M. C.; HOFFMEYER M. S. (Ed.). El ecosistema del estuario de Bahía Blanca. Publicación especial del Instituto Argentino de Oceanografía (CONICET-UNS). Bahía Blanca, Argentina, 2004. p.133-141.

HOFFMEYER, M. S.; BARRIA DE CAO, M. S Zooplancton assemblage from a tidal channel in the Bahía Blanca estuary, Argentina. Braz J. Oceanogr., v. 55, n. 2, p. 97-107, 2007.

IRIGOIEN, X.; FLYNN, K. J.; HARRIS, R. P. Phytoplankton blooms: a "loophole" in microzooplankton grazing impact?. J. Plankt. Res., v. 27, p. 313-321, 2005.

JOHANSSON, M.; GOROKHOVA, E.; LARSSON, U. Annual variability in ciliate community structure, potential prey and predators in the open northern Baltic Sea proper. J. Plankt. Res., v. 26, p. 67-80, 2004.

KARAYANNI, H.; CHRISTAKI, U.; WAMBEKE, F. V.; DALBY, A. P. Evaluation of double formalin-Lugol's fixation in assessing number and biomass of ciliates: an example of estimations at mesoscale in NE Atlantic. J. Microbiol. Meth., v. 56, p. 349-358, 2004

LEAKEY, R. J. G.; BURKILL, P. H.; SLEIGH, M. A. Planktonic ciliates in Southampton Water: abundance, biomass, productions and role in pelagic carbon flow. Mar. Biol., v. 114, p. 67-83, 1992.

LEAKEY, R. J. G.; FENTON, N.; CLARKE, A. The annual cycle of planktonic ciliates in nearshore waters at Signy Island, Antartica. J. Plankt. Res., v.16, p. 841-856, 1994.

LEWITUS, A. J.; KOEPFLER, E. T.; MORRIS, J. T. Seasonal variation in the regulation of phytoplankton by nitrogen and grazing in a salt-marsh estuary. Limnol. Oceanogr. v. 43, p. 636-646, 1998.

LONSDALE, D. J.; COSPER, E.; WOONG-SEO, M. K.; DOALL, M.; DIVADEENAM, A. S.; JONASDOTTIR, $\mathrm{H}$. Food web interactions in the plankton of Long Island bays, with preliminary observations on brown tide effects. Mar. Ecol. Progr. Ser., v. 134, p. 247-263, 1996

LORENZEN, C. J.; JEFFREY, S. W. Determination of chlorophyll in seawater. UNESCO Tech. Pap. mar. Sci., v. 35, p. 1-20, 1980.

LYNN, D. H.; ROFF, J. C.; HOPCROFT, R. R. Annual abundance and biomass of aloricate ciliates in tropical neritic waters off Kingston, Jamaica. Mar. Biol., v. 110 , p. 437-448, 1991 .

MCALICE, B. J. Phytoplankton sampling with the Sedgwick-Rafter cell. Limmnol. Oceanogr., v. 16, p. 19-28, 1971

MARCOVECCHIO, J. E.; FREIJE, R. H. Efectos de la intervención antrópica sobre sistemas marinos costeros: el estuario de Bahía Blanca. An. Acad. Nac. Cienc. Exactas Fis. Nat. B. Aires, v. 56, p. 115-132, 2004.

MONTAGNES, D. J. R.; LYNN, D. H.; ROFF, J. C.; TAYLOR, W. D. The annual cycle of the heterotrophic planktonic ciliates in the waters surrounding the isles of Shoals, Gulf of Maine: an assessment of their trophic role. Mar. Biol., v. 99, p. 21-30, 1988.

NIELSEN, T. G.; KIØRBOE, T. Regulation of zooplankton biomass and production in a temperate coastal ecosystem 2. Ciliates. Limmnol. Oceanogr., v. 39, p. 508-519, 1994.

PERILLO, G. M. E.; PICCOLO, M. C. Geomorphologic and physical characteristics of the Bahía Blanca Estuary. In: Perillo, G. M. E.; Piccolo, M. C.; Pino Quivira, M. (Ed.). Estuaries of South America: their geomorphology and dynamics. Berlin: Springer-Verlag, 1999. p. 195216. Environ. Sci. Ser.

PETTIGROSSO, R. E.; BARRIA DE CAO, M. S.; POPOVICH, C. A. Planktonic ciliates during a diatom bloom in Bahía Blanca Estuary, Argentina. I Aloricate. Oebalia v. 23, p. 21-31, 1997.

PETTIGROSSO, R E. Estudio taxonómico y ecológico de ciliados planctónicos (Ciliophora Choreotrichida y Strombidiida) del Estuario de Bahía Blanca, Argentina. Tesis (Doctoral). Universidad Nacional del Sur, Bahía Blanca, Argentina. 173p. 2001.

PETTIGROSSO, R. E. Planktonic ciliates Choreotrichida and Strombidiida from the inner zone of the Bahía Blanca estuary, Argentina. Iheringia v. 93. p. 117 - 126, 2003.

PETZ, W. Ciliophora. In: BOLTOVSKOY, D. (Ed.). South Atlantic zooplankton. Leiden: Backhuys Publisher, 1999. p. $265-319$.

PICCOLO, M. C.; PERILLO, M. E. Physical characteristics of the Bahía Blanca estuary Argentina. Estuar. coast. Shelf Sci., v. 31, p. 303-317, 1990.

PICCOLO, M. C.; PERILlO, G. M. E.; ARANGO, J. M. Hidrografía del estuario del Río Sauce Chico (Bahía Blanca). Geoacta, v.. 17, p. 13-23, 1990.

PIERCE, W. R.; TURNER, J. T. Ecology of planktonic Ciliates in marine food webs. Rev. Aquat. Sci., v. 6, p. 139-181, 1992.

POPOVICH, C. A.; MARCOVECCHIO, J. E. Spatial and Temporal Variability of Phytoplankton and Environmental Factors in a Temperate Estuary of South America (Atlantic Coast, Argentina ). Continent. Shelf Res., v. 28, n. 2, p. 236-244, 2008.

POPOVICH, C. A.; SPETTER, C. V.; FREIJE, R. H.; MARCOVECCHIO, J. E.. Dissolved Nutrients Availability during Winter Diatom Bloom in a Turbid and Shallow Estuary (Bahía Blanca, Argentina). J. coast. Res., v. 24, p. 95-102, 2008a.

POPOVICH, C. A; GUINDER, V. A.; PETTIGROSSO, R. Composition and dynamics of phytoplankton and aloricate ciliate communities from Bahía Blanca estuary. In: NEVES, R.; BARETTA, J.; MATTEUS M. (Ed.). Integrated coastal zone management in Latin America. Lisboa: IST Press, Scientific Publishers, 2008b. p. 255-270.

PUTT, M.; STOECKER, D. K. An experimentally determined carbon volume ratio for marine "oligotrichous" ciliates from estuarine and coastal waters. Limnol. Oceanogr., v. 34, p. 1097-1103, 1989. 
RASSOULZADEGAN, F.; LAVAL-PEUTO, M.; SHELDON, R. W. Partitioning of the food ration of marine ciliates between pico and nanoplankton. Hydrobiologia, v. 159, p. 75-88, 1988.

REVELANTE, N.; GILMARTIN, M. Seasonal Cycle of the Ciliated Protozoan and Micrometazoan Biomass in a Gulf of Maine Estuary. Estuar. coast. Shelf Sci., v. 25, p. 581-598, 1987.

SANDERS, R. W.; WICKHAM, S. A. Planktonic protozoa and metazoan: predation, food quality and population control. Mar. Microbiol. Food Webs, v. 7, p. 197-223, 1993.

SIME-NGANDO, T.; GOSSELIN ROY, M. S.; CHANUT, J. P. Significance of planktonic ciliated protozoa in the Lower St. Lawrence Estuary: comparison with bacterial, phytoplankton and particulate organic carbon. Aquat. Microbiol. Ecol., v. 9, p. 243-258, 1995.

SMETACEK, V. The annual cycle of protozooplankton in the Kiel Bight. Mar. Biol., v. 63, p. 1-11, 1981.

STOECKER, D. K.; GIFFORD, D. J.; PUTT, M. Preservation of marine planktonic ciliates: losses and cell shrinkage during fixation. Mar. Ecol. Progr. Ser., v. 110, p. 293-299, 1994.

STRICKLAND, J. D. H.; PARSON, T. R. A practical handbook of seawater analysis. Ottawa: Fish. Res. Board of Canada, 1972. 310 p.
SIEBURTH, J. MCN.; SMETACEK, V.; LENZ, J. Pelagic ecosystem structure: Heterotrophic compartments of the plankton and their relationship to plankton size fractions. Limnol. Ocenogr., v. 23, p. 1256-1263, 1978.

TAKASHI, O.; TANIGUCHI, A. Standing crop of planktonic ciliates in the East China Sea and their potential grazing impact and contribution to nutrient regeneration. Deep Sea Res., II., v. 50, p. 423-442, 2003.

TECHNICON® AUTOANALYZER II. Silicates in water and seawater. Industrial Method, 1973. 186-72W/B.

TREGUER, P.; LE CORRE, P. Manuel d'analyse des sels nutritifs dans l'eau de mer. Universite Bretagne Occidentale, 1975. p. 11-22.

TRIGUEROS, J. M.; ORIVE, E. Seasonal variations of diatoms and dinoflagellates in a shallow, temperate estuary, with emphasis on neritic assemblages. Hydrobiologia, v. 444, p. 19-133, 2004.

VERITY, P. G. Grazing, respiration, excretion, and growth rates of tintinnids in Narragansett Bay, Rhode Island. Estuar. coast. Shelf Sci., v. 24, p. 671-690, 1985.

(Manuscript received 19 December 2008; revised 19 May 2009; accepted 29 May 2009) 